\title{
Vegetable Grafting: A Multidimentional Approach for Crop Management in Vegetables
}

\author{
Shriram Ratan Pradhan*, G.S. Sahu, P. Tripathy, S.K. Dash, \\ B. Mishra, R. Jena and T.R. Sahoo \\ Orissa University of Agriculture and Technology, Bhubaneswar-751003, Odisha, India \\ *Corresponding author
}

\begin{tabular}{|l|}
\hline Ke y w o r d s \\
Vegetable grafting, \\
Verticillium wilt, \\
Quality, Ralstonia, \\
Solanaceae, \\
Cucurbitaceae, \\
Abiotic stress. \\
\hline Article Info \\
\hline $\begin{array}{l}\text { Accepted: } \\
\text { 26 September } 2017 \\
\text { Available Online: } \\
\text { 10 October } 2017\end{array}$ \\
\hline
\end{tabular}

\section{A B S T R A C T}

Grafting in vegetables is a comparatively recently popularized approach among vegetable growers worldwide. Initially the technique was for controlling soil borne diseases which is still of much importance in today's intensive agriculture. But with modification in grafting approaches and other related researches, this has now become a multifaceted approach being used for several purposes. Grafting is an important integrated pest management strategy to manage soil borne pathogens and other pests of solanaceous and cucurbitaceous crops using suitable rootstocks. Important diseases managed by grafting are caused by fungus such as Verticillium and Fusarium; oomycetes like Phytophthora; bacteria, particularly Ralstonia and root knot nematodes. Grafted seedlings are much favored in hydroponics where the chances of rapid spread of noxious diseases, once infected, is high. Due to limited availability of arable land and the high market demand for vegetables around the world, vegetables are frequently cultivated under unfavorable soil and environmental conditions like thermal stress, drought and flooding, contamination by persistent organic pollutants and low soil temperature and high soil salts, especially under protected cultivations where successive cropping or continuous farming is routinely practiced. One way to reduce losses in production caused by such abiotic stresses in vegetables would be to graft them onto rootstocks capable of reducing the effect of external stresses on the shoot through vigorous attainment of soil nutrients, avoidance of infection by soil pathogens and tolerance of abiotic stresses. Vegetable grafting has also been safely adapted for the production of organic as well as environmentally friendly produce and minimizes uptake of undesirable agrochemical residues. The quality characteristics like firmness, texture, flavor and health compounds might be affected by grafting as a result of the translocation of metabolites associated with fruit quality to the scion through the xylem and/or modification of the physiological processes of the scion.

\section{Introduction}

Grafting can be defined as the natural or deliberate fusion of plant parts so that vascular continuity is established between them and the resulting genetically composite organism functions as a single plant. Commercial vegetable grafting originated in
Japan and Korea and was practiced for about 30 years. At first the cultivation of grafted plants in vegetables started to challenge the serious crop loss caused by infection of soilborne diseases aggravated by successive and intensive cropping. Even though grafting has 
been a mere common practice in fruit trees since ages, vegetable grafting is of recent popularization in a commercial scale (Sakata et al., 2007). It was introduced to Western countries in the early 1990s and is currently being globally practiced using local scion cultivars and introduced rootstocks. The wide popularization of protected cultivation using greenhouse technology for the production of vegetables in the late $1950 \mathrm{~s}$ provided the momentum for generalized production and use of grafted vegetables. In current era of organic and sustainable agriculture generous use of inorganic chemical fertilizers and synthetic pesticides should be minimized for the production of ecofriendly produces (Davis et al., 2008; Lee and Oda, 2003; Sakata et al., 2007). Continuous cropping is unavoidable in greenhouses, which again leads to reduction in yield and quality of the produce due to the menace ofsoil borne pathogens and nematodes. Since soil sterilization can never be complete, grafting has become an essential technique for the production of repeated crops of vegetables grown in both greenhouse and open field condition. It has been wellestablished that the use of suitable rootstocks can minimize the problems associated with modern agriculture like successive cropping and different stress tolerance (Hoyos Echeverria, 2010; Lee and Oda, 2003). Since the plants are cultivated under the protected structures year-round, they frequently are subjected to extreme environmental conditions in the high tunnels during offseason cultivation (Lee, 2008).

As a result farmers frequently encounter various problems other than soil borne pathogens caused by successive as well as off-season cropping such as low temperatures during the winter, high humidity in the high tunnels, insufficient light intensity, and lack of well-balanced fertilization. The produces grown under these heavily stressed conditions frequently suffer from heavy incidence of soil-borne diseases, abnormal abiotic stresses which lead to physiological disorders, and quality deterioration. In addition to the widely recognized advantages of disease tolerance and high crop yields through vigorous attainment of nutrients, grafting technology is also highly effective in ameliorating crop losses caused by adverse environmental conditions such as low soil temperature and high soil salts, especially under protected cultivations where successive cropping or continuous farming is routinely practiced. Grafted seedlings are much favored in hydroponics farming systems where the chances of rapid spread of noxious diseases, once infected, is high.

\section{Multidimensional aspects of vegetable grafting}

\section{Tolerance to soil borne biotic stress}

Grafting to tackle soil borne diseases has rapidly expanded its horizon to different solanaceous and cucurbit vegetables. The contributing factors that have led to such increased expansion of grafting include: increased pathogen population densities due to intensified production systems, heavy reliance on susceptible but popular cultivars to meet specific market demands (Sakata et al., 2007), arising of new major pathogen through introduction or minor pest resurgence, the rapid adoption of green/polyhouse production, growing demand for organic food, and the loss of methyl bromide as a broad spectrum soil fumigant to manage soil borne pathogens and pests. So as an alternative effort to tackle such problem based on integrated pest management approach as a longer term strategy, grafting represents a viable option with enough potential to mitigate the above mentioned biotic stress. The use of grafting in vegetable production systems has expanded to manage a broad range of pathogens including different ranges of fungi, oomycetes, bacteria, nematodes and viruses. 


\section{Grafting against Verticillium wilt}

Grafting has been commonly used to manage verticillium wilt in tomato and brinjal but its use for this purpose is quite rare in case of cucurbits. $V$. dahliae is the primary pathogen of concern among all the races of this pathogen. Solanum torvum (Turkey berry) is commonly used as rootstock for brinjals, accounting over $50 \%$ area of grafted brinjals in Japan (Oda, 1995). In case of grafted brinjal plants with $S$. torvumas rootstock, suppressed Verticillium infection allowing only some mild symptoms; increased root biomass in the grafted treatments, and produced higher yields comparable to methyl bromide sterilized treatments (Bletsos, 2006). This rootstock was also observed to be providing greater resistance for this pathogen than S. sisymbriifolium (Bletsos et al., 2003). In Italy, $S$. torvum rootstocks offered control of root knot nematode but was not effective against Verticillium pathogen after repeated cropping cycles (Garibaldi et al., 2005). In follow up work, brinjal grafted onto S. torvum had a wilt incidence of 20\%compared to $97 \%$ wilt in non-grafted plants. S. torvum was again observed to minimize disease incidence and increase yield under the combined pressure of Verticillium and Meloidogyne (Curuk et al., 2009).

Among the 33 cucurbit rootstocks evaluated, all rootstocks showed some symptoms due to colonization by $V$. dahlia. Among those the most tolerant ones found to be were Cucurbita pepo and Lagenaria siceraria. Melon and watermelon were found to be susceptible and highly susceptible, respectively (Paplomatas et al., 2000).

Mechanisms of grafting to combat Verticilliumin the infested soils includes increased root vigor and biomass (Bletsos et al., 2003) and associated increased water and nutrient uptake (Lee, 1994). As per the conclusion provided by Klosterman the impact of reduced infestation might be due to the low success rate of inoculum penetration and colonization into vascular tissue, and even if the colonizationoccurs it is a relatively slow process (Klosterman et al., 2009).The decreased the rate of colonization of pathogen in the vascular tissue might be another reason for a reduced rate of wilt (Paplomatas et al., 2002). The role of root exudates in suppressing Verticillium growth in the rhizosphere of susceptible and resistant rootstocks is also of importance(Liu et al., 2009).The Verticillium wilt resistant tomato rootstock, 'Lydl', when grafted with brinjal scions, eluted some chemicals of allelopathic nature that inhibited mycelial growth of $V$. dahlia. The root exudate profile emitted from plants grafted with rootstock was distinctly different than from non-grafted roots providing details about specific constituents having some role in suppression of the pathogen (Liu et al., 2009).

\section{Grafting against Fusarium pathogens}

Fusarium species are commonly persistent in soils for years by colonizing inside different alternate hosts in a symptomless manner, inside soil debris or by persistent survival means like chlamydospores. Therefore crop rotation has not been proved to be of much success in properly controlling Fusarium diseases. Fusarium species have a prolific capacity to recolonized is infested soils and can be readily re-introduced into production areas on contaminated soil, equipment and plant tissue (Louws et al., 2010). S. torvum rootstock also conferred resistance to $F$. oxysporum $f$. $s p$. melongenae limiting fusarium wilt incidence in brinjal scions (Gousset et al., 2005). But managing Fusarium wilt through grafting has attained much success in case of cucurbits than that of solanaceous vegetables. Non-host resistance (i.e. exploiting host pathogen incompatibility) 
using interspecific or intergeneric grafting has proven to be an effective management tactic, particularly in cucurbitcrops. Hence, the use of interspecific hybrids is commonly used in case of watermelon. Bottle gourd is the most important rootstock against this pathogen in watermelon in Japan (Sakata et al., 2007). The rootstock 'Shintoza' is preferred in Spain because of its effectiveness against all races of Fusarium and yield stability contribution as compared to the non-grafted plants. (Miguel et al., 2004).

Grafting of cucumbers found popularity in Japan when $F$. oxysporum $f$. sp. cucumerinum resistance was combined with rootstocks that enhanced yield and provided environmental stress tolerance (Sakata et al., 2008). Fig leaf gourd (Cucurbita ficifolia) is a popular rootstock for cucumber sinceit shows good to excellent resistance to fusarium wilt (Lee and Oda, 2003), with low temperature tolerance thus preferred in the winter production season. The rootstock, ISHc 'Shintosa' that offers fusarium wilt resistance and heattolerance is preferred for summer production in cucumber (Sakata et al., 2008). Cucumber plants grafted onto Cucurbitamoschata offered tolerance to both fusarium wilt and phytophthora blight (Sakata et al., 2008; Takahashi and Kawagoe, 1971). Burr cucumber (Sicyosangulatus L.) also provides fusarium wilt resistance along with root knot nematode control but is susceptible to damping-off and gummy stem blight (Sakata et al., 2008).

\section{Grafting against bacterial wilt pathogens}

Bacterial wilt caused by Ralstonia solanacearumis one of the most important bacterial diseases in regions of the world. It's also one of the most important objective towards which vegetable grafting of solanaceous vegetables are concentrated against, especially in the tropical coastal belts of the world. Infested plant typically shows complete plant collapse very quickly. With the help of a wide host range of plants including weed species, the bacteria remains persistent in soil for many years causing havoc in crop production. Soil disinfestation is effective for a short period only. The resistant varieties are not that effective due to wide range of pathogens strains and linked gene effect with undesirable fruit characteristics. So the best alternative for this problem is grafting with suitable rootstocks.

The AVRDC recommends brinjal rootstocks for tomato production for bacterial wilt resistance and in cases when flooding may occur, otherwise H7996 is recommended (Black et al., 2003). Solanum toxicarium was found to be resistant to 5 diverse (termed I to V) Ralstonia solanacearums trains whereas $S$. sisymbriifolium was only resistant to strain III and $S$. torvum was resistant to strain I, II and V (Matsuzoe et al., 1993). S. torvum was the most effective rootstock for brinjal in Italy (Bilotto et al., 2006) and is considered tolerant to pathogen strains (Gousset et al., 2005). The protection mechanism by use of rootstock were found not due to prevention of entry of bacteria into the xylem tissue in the root. But the resistance mechanism was due to limited colonization of bacteria in the lower stem (Nakaho et al., 2000; Prior et al., 1996). Similar results were shown by Grimault and Prior who found reciprocal grafts (succeptible scion used as rootstock and resistant rootstock used as scion) to be succeptible to disease, which might have been associated with reduced colonization of the bacteria into the lower stem (Grimaultand Prior, 1994).

\section{Grafting against root knot nematodes}

Root knot nematodes are obligate endoparasites with a broad host range of vegetation. This especially causes severe yield losses, especially in solanaceous 
vegetables. Meloidogyne incognita, $M$. arenaria, M. javanicaand M. hapla are the four main species affecting different crops causing too much loss to farmers. These are disseminated through contaminated soil, plant root debris or infected plants. S. torvum and $S$. peruvianum also offer resistance to Meloidogyne incognita (Rodríguez et al., 2009). Root knot nematode management in brinjal has been accomplished with the interspecific hybrid rootstock 'Brigeor' (Ioannou, 2001) and S. torvum (Curuk et al., 2009).

Bur cucumber and the African horned cucumber have the best nematode tolerance which can be used in grafting among cucurbits for providing protection from nematodes (Lee and Oda, 2003; Sakata et al., 2008). Cantaloupes (Cucumis melo L.) grafted on rootstocks $C$. moschata and $C$. metuliferus reduced Meloidogyne incognita race 3 induced galling incidence with the later rootstock considered moderately resistant (Siguenza et al., 2005).

\section{Grafting against pests}

Although pests have never been one of the focal points in objectives in vegetable grafting but some important research finding have been observed at different places. Wild Solanum $s p$. has been reported to be used as rootstock to reduce the density of whiteflies for reduced incidence of white-fly transmitted virus symptoms (Alam et al., 1995). Carmine spider mite (Tetranychuscinnabarinus) resistance has been conferred to cucurbit scions by using Lagenariaas the rootstock(Edelstein et al., 2000).Tomato grafted onto wild Solanum selections also have been observed to reduce the incidence of the sweet potato whitefly (Bemisiatabaci), potato psyllid (Bactericeracockerelli) and aphids (Aphis gossypii) (Alvarez-Hernandez et al., 2009).

\section{Grafting against parasitic pests and weeds}

Orobanche species like Orobancheaegyptiaca and $O$. ramosa prominent on tomato fields of Mediterranean countries, were found to be controlled by grafting on a resistant rootstock (Dor et al., 2010). Although this source of resistance has not been deployed into commercial rootstocks to date.

\section{Grafting for quality improvement}

\section{Physical quality}

The physical appearance of vegetables is of foremost importance from consumer's point of view affecting the purchasing decisions, which is characterized by size, shape, color, condition and absence of defects (Kays, 1999). By different research studies it has been reported that the average fruit weight and size of solanaceous and cucurbitaceous vegetables are often influenced by grafting, which is also an important component of yield. One of the most important physical quality, fruit size was reported to be increased in the grafted plants, as they were resistant to soilborne disease, having strong root systems and increased photosynthesis (Qi et al., 2006).Similar results showing increased fruit size were also observed in case of brinjal and tomato, respectively (Passam et al., 2005; Pogonyi et al., 2005). The incidence of the physiologicaldisorder affecting the physical appearance has been reported to be closely associated with the rootstock especially in case of cucurbits. Vigorous rootstocks, such as interspecific hybrids between C. maxima $\times$ C.moschata, caused severe incidence of premature internal decay in 'Keumssaragi' oriental melons by absorbing absorb more nitrogen fertilizers and less calcium into the fruits (Chung, 1995).Grafting was also reported to improve the glassy look of flesh in melon (Taussiget al., 1996).Firmness of fruits were also affected in some extent due to 
grafting. Fruits from grafted watermelon on Lagenaria rootstocks (Yetisir et al., 2003), and C. maxima $\times C$. moschata ('RS841' and 'Shintoza Camelforce') (Huitrón-Ramírez et $a l ., 2009$ ) were firmerby $24 \%$ and $27 \%$, respectively compared to the ungrafted plants. Rind thickness of fruits from grafted watermelon vineswasalso reported to be increased by $21 \%$ (Yetisir et al., 2003) and $17 \%$ (Proietti et al., 2008) than the fruits from ungrafted plants. Although this physical property enhancement resulted in relatively higher wastage at the time of consumption but on the other hand it guaranteed better postharvest storage and prevention of injury during handling.

\section{Flavor compounds}

Plants have the capacity to synthesize, accumulate and emit volatiles that may act as aroma and flavor molecules due to interactions with human receptors. These lowmolecular-weight substances derived from the fatty acid, amino acid and carbohydrate pools constitute a heterogenous group of molecules with saturated and unsaturated, straight-chain, branched-chain and cyclic structures bearing various functional groups (e.g. alcohols, aldehydes, ketones, esters and ethers) and also nitrogen and sulfur. The total sugar content of watermelons grafted onto bottle gourd ( $L$. siceraria) rootstock was reported to be lower than in self-rooted watermelons (Yao et al., 2003; Qian et al., 2004; Liu et al., 2006). Proietti et al., (2008) demonstrated that miniwatermelon grafted onto the commercial hybrid rootstock 'PS 1313' (C. maxima $\times C$. moschata) exhibited higher titratable acidity (TA), and a higher TSS/TA ratio. The higher value of TSS/TA ratio represents a central parameter regarding the flavor of the fruit because it describes a good balance between sweetness and acidity in fruits. In a general conclusion by many researchers the changes in the scion are controlled by the rootstock mainly through controlled uptake, synthesis, and translocation of different minerals and plant hormones (Lee and Oda, 2003).Grafting influences absorption and translocation of phosphorus, nitrogen, magnesium and calcium (Ruiz et al., 1997; Pulgar et al., 2000; Rouphael et al., 2008). It has been suggested that improved nutrient uptake in grafted seedlings increases photosynthesis, which is particularly noticeable under less than optimal growing conditions such as low sunlight and $\mathrm{CO}_{2}$ concentration especially in protected structures (Hu et al., 2006). These conditions allow grafted plants to produce higher yields compared to ungrafted plants, sometimes with improved sugar contents (Xu et al., 2006a, b).

\section{Health-related compounds}

As per the study by Huang et al., (2009) an increase of vitamin $\mathrm{C}$ contents was reported in cucumber fruits harvested from plants grafted onto fig leaf gourd. Lycopene concentration was related to the high $\mathrm{K}$ concentration in the fruit in tomato. It is also known as an anticancerous compound. Proietti et al., (2008) demonstrated that mini-watermelon grafted onto the commercial hybrid rootstock 'PS 1313' (C. maxima $\times$ C. moschata) increased the lycopene concentration by $40 \%$ than the fruits from ungrafted plants.

\section{Grafting Against Abiotic Stress}

\section{Grafting for cold tolerance}

Cold stress is one of the most important factors the crop plants of temperate and subtropical regions are facing through chilling and freezing injury thus affecting the yield and quality parameters. Especially the production of vegetables in areas of cold and even mild climate conditions are affected severely during the winter (sometimes during spring also) due to chilling and suboptimaltemperature conditions. The temperature limit 
for growth of most of the chilling-sensitive fruit vegetables, such as pepper, brinjal, cucumber, tomato and melon is about $8-12 \circ \mathrm{C}$ (Criddle et al., 1997). Below this limit, vegetables originating from tropical or subtropical areas suffer from different disorders (leading to distortion or death of plant parts), depending on the interval and intensity of exposure to cold (Venema et al., 2005). Tomato grafted onto a cold-tolerant rootstock revealed a higher capacity to adjust their root/shoot ratio to suboptimal roottemperature (Venema et al., 2008).This might be due to the functional equilibrium established between root and shoot of the grafted plant, allowing the root system to overcome restrictions in water and nutrient uptake. For watermelon, grafting onto Shintosa-type (an interspecific squash hybrid, Cucurbita maxima $\times$ C. moschata) rootstocks is used to advance the planting date during cool periods (Davis et al., 2008).For cold tolerance in cucumber, fig leaf gourd (Cucurbita ficifolia) and bur cucumber (Sicosangulatus L.) are popularly used as rootstocks. Fig leaf gourd has got a distinctive trait with an optimum root temperature requirement of around $15{ }^{\circ} \mathrm{C}$, which is $6{ }^{\circ} \mathrm{C}$ lower than that of cucumber roots (Tachibana, 1982; Ahn et al., 1999; Rivero et al., 2003). These two rootstocks also improved the vegetative growth and early yield at suboptimal temperatures (Zhou et al., 2007).It was shown, that both uptake (Masuda and Gomi, 1984; Tachibana, 1982, 1987) and transport (Choi et al., 1995) of the macronutrients, particularly nitrate and phosphate, increased in fig leaf gourds compared with cucumber rootstocks in response to decreased root-zone temperatures. Shibuya et al., (2007) also reported that grafting of a cucumber scion onto a squash rootstock (Cucurbita moschata) could tolerate suboptimal temperatures compared with a selfgraftedone. Scions grafted onto lowtemperature tolerant cucurbit a rootstocks close the stomata much later compared with scions grafted onto sensitive ones, or scions grafted onto their own. Thus, transpiration is maintained and such plants perform better and experience cell death later (Yu et al., 1999).In contrast, cold-tolerant tomatoes, such as $S$. habrochaites, decline the stomatal conductance resulting in a stomatal closure, while the stomata of cold-sensitive species remain open until chilling temperatures of 5 ${ }^{\circ} \mathrm{C}$, due to which, they became flaccid and suffered damage (Bloom et al., 2004).

\section{Grafting for high temperature tolerance}

High temperatures above the optimal range required for plant growth leads to a series of complex morphological, physiological, biochemical and molecular changes that affect plant growth and productivity adversely (Wang et al., 2003) by different means such as growth reduction, decrease in the photosynthetic rate, increase in respiration, assimilate partitioning towards the fruits, osmotic and oxidative damage, reduced water and ion uptake/movement, cellular dehydration etc. On the other hand, plants activate stress-responsive mechanisms, such as production of heat shock proteins, osmo protection, and stabilization of enzymes and membranes. So the rootstocks need to improve these defense mechanisms to establish their role in high temperature tolerance in grafted plant. Since brinjals are better adapted to tropical hot conditions with better tolerance against high soil temperature, the use of brinjals as rootstocks for tomato at higher temperature seemed to be more promising (Abdelmageed and Gruda,2009), although it lead to decreased total fruit dry weight. It has also been recorded that grafting of tomato onto brinjals reduced electrolyte leakage under high temperature stress, indicating less membrane damage and a higher ability to retain solutes and water (Abadelhafeez et al., 1975; Abdelmageed and 
Gruda, 2009). The use of a heat-tolerant tomato (cv. Summerset) as a rootstock also failed to improve the yield. However, testing brinjals grafted onto a heat-tolerant rootstock (cv. Nianmaoquie) seemed to be promising and resulted in a prolonged growth stage and yield increase (Wang et al., 2007). In pepper highest yields were recorded under hightemperature conditions for rootstocks recommended by the AVRDC such as $C$. annuumcv. Toom-1 and 9852-54 (Palada and $\mathrm{Wu}, 2008)$. Grafting tomato onto a heat tolerant rootstock (L. esculentum cv. RX-335) resulted in a decreased hydrogen peroxide concentration indicating the lower oxidative stress (Rivero et al., 2003a). The tomato grafted onto brinjals exhibited also a lower proline level but higher ascorbate concentrations compared with self-grafted tomato (Abadelhafeez et al., 1975).

\section{Grafting against water stress}

For reducing the yield loss and improving the water use efficiency in the drought prone areas, use of moisture stress tolerant rootstocks in grafting can be a viable option. (García-Sánchez et al., 2007; Satisha et al., 2007). Grafted mini-watermelons onto a commercial rootstock (PS 1313_:Cucurbita maxima $\times$ Cucurbita moschata) under moisture stress condition, produced $60 \%$ higher marketable yield than ungrafted melons (Rouphael et al., 2008), which might be due to an increased efficacy in water and nutrient uptake, indicated by a higher $\mathrm{N}, \mathrm{K}$, and $\mathrm{Mg}$ concentration in the leaves and higher $\mathrm{CO}_{2}$ assimilation. Holbrook et al., (2002) on his grafting experiments with ABA deficient mutants of tomato showed that stomata can close independently of the leaf water status suggesting that there is a chemical signal produced by the roots that controls stomatal conductance. Since brinjal root system is more effective in water uptake than tomato root systems, it mightbe used as a rootstock for tomato under drought conditions.
Flooding and submergence are some of the major abiotic stresses causing serious problems for the growth and yield of flood sensitive crops especially in coastal and low land regions of the world. Grafting improved flooding tolerance of bitter gourd when grafted onto luffa (Liao and Lin, 1996) which might be due to depression of photosynthetic rate, stomatal conductance, transpiration, soluble proteins, and/or activity of RuBisCO. For managing such problems in the lowland tropics, the AVRDC recommends growing tomatoes on brinjals 'EG195' or 'EG203' and pepper on chili accessions 'PP0237-7502', 'PP0242-62' and 'Lee B' (AVRDC, 2003, 2009). The high percentage of plant survival in grafted plantsin high intense rains during monsoon at Navsari expressed the suitability of Solanum torvum as rootstock to perform well under such conditions. A high moisture situation in the soil causes oxygen starvation and is often associated with so many soil borne problems like wilts, root knot nematodes etc. The vigorous root system of Solanum torvum and resistance to soil diseases or pests, tolerance to abiotic stress, selective absorption of available soil nutrients conferred a high degree of vigour to the scion (Davis et al., 2008; Lee and Oda, 2003 and Lenz, 1970). Hu et al., (2006) have also suggested that improved nutrient uptake in grafted seedlings increases photosynthesis under week sunlight conditions and such conditions generally prevails during rainy season under south Gujarat conditions.

\section{Grafting for plant vigour promotion}

As a generalized observation, the root systems of rootstocks are extensively spread over large area inside soil and more vigorous, as a result of which they absorb water and nutrients much more efficiently as compared to non-grafted plants, due to this particular occurrence, in case of grafted plants less fertilizers are recommended sometimes. As reported by Salehi-Mohammadi et al., (2009) 
in watermelons, it is recommended to reduce the amount of chemical fertilizers application to about one-half to two-third as compared to the standard recommendation for non-grafted plants. That is of importance especially in case of nitrogen fertilizers during early seedling growth and proper and early fruit setting. The frequency of other agrochemical application like fungicides can be reduced to a great extent by use of vigorous rootstocks. Cytokinin composition in xylem sap of grafted and non-grafted vines, vary greatly in various cucurbits. The higher cytokinin concentration in the ascending xylem sap contributes sufficiently to high vigour of the plant. In cucumber, vigorous root system of the rootstock can effectively absorb water so that less frequent irrigation may be practiced. The differences in quality, yield and earliness in brinjal could be attributed to the different growth characteristics of the cultivars and to their compatibility with the rootstock. Thus, (Suzuki \& Morishita, 2002; Sebahattin et al., 2009) showed that Solanum torvum is a vigorous rootstock, and a graft combination of a vigorous cultivar with an equally vigorous rootstock reduces the amount of fertilizer required for the same yield. Earliness could also be associated with the high vigour of the rootstock. Gisbert et al., (2011) have mentioned that the earliness was observed mainly in the interspecific hybrids, respective between S. melongena and S. aethiopicum or S. incanum.

\section{Grafting for yield increase}

Many researchers has reported an increase in yield of produce which may be due to higher plant vigour, protection against biotic and abiotic stresses. In oriental melons, fresh fruit weight increase of $25-55 \%$ have been reported as compared to own-rooted plants. These yield increase were closely correlated with the maintenance of good plant vigor until late in the growing season in addition to disease resistance. The marketable yield in grafted brinjal was significantly higher than non-grafted ones, although there was no significant difference between the grafted variants. The range of variation was relatively small between grafted variants. The not grafted brinjals variant yield (Aragon $F_{1}$ ) harvest was only of $44.6 \mathrm{t} / \mathrm{ha}$, with over $15 \mathrm{t}$ less than the registered yield of grafted brinjals variant (Bogoescu and Doltu, 2015). Similar results were obtained with tomato, where $54 \%$ increase of marketable yield was obtained with 'Kagemusia' and 51\% with 'Helper' rootstocks (Chungand Lee, 2007). Similar yield increase have been reported by other researchers on watermelon, cucumber (Lee and Oda, 2003), melon, pepper, and brinjal.

As already mentioned, grafting in vegetables is an multidimensional approach leading to the solution of many problems in the field starting from the problems arising from conventional cultivation such as use of methyl bromide for soil sterilization, rapid spread of diseases caused by successive cropping, low soil temperature damage during the early stages, heavy use of pesticides and chemical fertilizers, and economic use of irrigation water. This can be an important part of the ever growing organic cultivation due to its ecofriendly pesticide free pest management approach. It has also got tremendous opportunity in case of intensive cultivation inside protected structure along with systems like hydroponics to minimize disease incidence. The agronomical and physiological processes that affect the fruit quality of grafted plants have received much research attention especially for watermelon, melon, cucumber and tomato and to a lesser degree for brinjal and pepper. So in a world of quality consciousness (without depending on chemicals), grafting can play a major role for tapping this opportunity. Grafting is also a promising tool to enhance plant performance 
of vegetables from both Cucurbitaceae and Solanaceae under different abiotic stresses. Several effective rootstocks to tackle these are already in practical use for this purpose. So in this current scenario of climate change, there is a need of such rootstocks for advancing the vegetable cultivation for meeting the ever increasing population of the world. But the desired rootstock traits are fairly complex, multi-gene ones needing practical selection tools like genetic markers, on which research works are under progress. In this review all the beneficial approaches of grafting for a healthy and beneficial vegetable production are covered, which might throw some light on the huge potential of grafting that is still untapped. Through the years, vegetable grafting has come a long way since its origin in Japan and China. Even though the benefits of using grafted seedlings are now fully recognized over the world, production of uniform, healthy grafted seedlings at reasonable prices is the key point for wider use, especially in those countries with limited experience.

\section{References}

Abadelhafeez, A.T., Harssema, H. and Verkerk, K., 1975. Effects of air temperature, soiltemperature and soil moisture on growth and development of tomato itself andgrafted on its own and eggplant rootstock. Sci. Hortic., 3, 65-73.

Abdelmageed, A.H. A. and Gruda, N., 2009. Influence of grafting on growth, developmentand some physiological parameters of tomatoes under controlled heat stressconditions. Eur. J. Hortic. Sci., 74 (1), 16-20.

Ahn, S.J., Im, Y.J., Chung, G.C., Cho, B.H. andSuh, S.R., 1999. Physiological responses ofgrafted-cucumber leaves and rootstock roots affected by low root temperature.Sci. Hortic, 81, 397-408.

Alam, M.Z., Hossain, M.M., Choudhury, D.A.M., Uddin, M.J., Haque, N.M.M., 1995.Effect of grafting technology on suppression of whitefly (Bemisiatabaci Gennadius) disseminating virus diseases in tomato. Ann. Bangladesh Agric., 5, 91-98.

Alvarez-Hernandez, J.C., Cortez-Madrigal, H., Garcia-Ruiz, I., Ceja-Torres, L.F. and Petrez-Dominguez, J.F., 2009. Incidence of pests in grafts of tomato (Solanum lycopersicum) on wild relatives. RevistaColombiana De Entomologia, 35, 150-155.

AVRDC, 2003. Guide. Grafting tomatoes for production in the hot-wet season.Asian Vegetable Research and Development Center, Publ. No\#03-551, Shanhua,Tainan, Taiwan, 6 pp. (www.avrdc.org/fileadmin/pdfs/grafting tomatoes.pdf).

AVRDC, 2009. Guide. Grafting sweet peppers for production inthe hot-wet season. Asian Vegetable Research and DevelopmentCenter, Publ.-No 09-722-e, Shanhua, Tainan, Taiwan, 8 pp. (www.libnts.avrdc.org.tw/fulltext pdf/FLYER/f0002.pdf).

Bilotto, M., Morra, L. andVerazza, A., 2006. Solanum torvum confirmed as the idealrootstock for aubergine./Solanum torvumsiconfermaportinnestoideale permelanzana. InformatoreAgrario, 62, 3134.

Black, L., Wu, D., Wang, J., Kalb, T., Abbass, D. and Chen, J., 2003. Grafting tomatoesfor production in the hot-wet season. AVRDC International Cooperators' Guide.AVRDC publication.

Bletsos, F., Thanassoulopoulos, C. andRoupakias, D., 2003. Effect of grafting on growth,yield, and Verticillium wilt of eggplant. Hortscience, 38, 183-186.

Bletsos, F.A, 2006. Grafting and calcium cyanamide as alternatives to methyl bromidefor greenhouse eggplant production. ScientiaHorticulturae, 107, 325-331.

Bloom, A.J., Zwieniecki, M.A., Passioura, J.B., Randall, L.B., Holbrook, N.M. and St. Clair,D.A., 2004. Water relations under root chilling in a sensitive and tolerant tomatospecies. Plant Cell Environ, 27, 971-979.

Bogoescu, M. and Doltu, M., 2015. The eggplants 
crop technology optimizationby grafting. Bulletin UASVM Horticulture, 72(2), 313317.

Choi, K.J., Chung, G.C., Ahn, S.J., 1995. Effect of root-zone temperature on the mineralcomposition of xylem sap and plasmamembrane $\quad \mathrm{K}^{+}-\mathrm{Mg}^{2+}-$ ATPase activityof grafted-cucumber and figleaf gourd root systems. Plant Cell Physiol., 36,639-643.

Chung, H.D. and Lee, J.M., 2007. Rootstocks for grafting. In: Horticulture in Korea. KoreanSociety for Horticultural Science, pp. 162-167.

Chung, H.D., 1995. Studies on the occurrence causes and prevention of fermentationin melon fruit, Cucumis melo L. var. makuwaMak. cv. Geumssaragieuncheon. Res. Rep. Kyungpuk Provincial RDA, Korea.

Criddle, R.S., Smith, B.N. and Hansen, L.D., 1997. A respiration based description of plantgrowth rate responses to temperature. Planta, 201, 441-445.

Curuk, S., Dasgan, H.Y., Mansuroglu, S., Kurt, S., Mazmanoglu, M., Antakli, O. andTarla,G., 2009. Grafted eggplant yield, quality and growth in infested soil with Verticillium dahliae and Meloidogyne incognita. PesquisaAgropecuariaBrasileira, $\quad 44$, 1673-1681.

Davis, A.R., Perkins-Veazie, P., Hassell, R., Levi, A., King, S.R. and Zhang, X.P., 2008. Grafting effects on vegetablequality. Horticulture Science, 43: 1670-1672.

Dor, E., Alperin, B., Wininger, S., Ben-Dor, B., Somvanshi, V.S.,Koltai, H., Kapulnik, Y. and Hershenhorn, J., 2010. Characterization of a novel tomato mutant resistant tothe weedy parasites Orobanche and Phelipanche spp. Euphytica, 171, 371-380.

Edelstein, M., Tadmor, Y., Abo-Moch, F., Karchi, Z. and Mansour, F., 2000. The potential ofLagenaria rootstock to confer resistance to the carmine spider mite, Tetranychuscinnabarinus (Acari: Tetranychidae) in Cucurbitaceae. Bull. Entomol. Res., 90,113-117.

García-Sánchez, F., Syvertsen, J.P., Gimeno, V., Botia, P. and Perez-Perez, J.G., 2007.Responses to flooding and drought stress by two citrus rootstock seedlings withdifferent water-use efficiency. Biol. Plant., 130, 532-542.

Garibaldi, A., Minuto, A. andGullino, M.L., 2005. Verticillium wilt incited by Verticillium dahliae in eggplant grafted on Solanum torvum in Italy. Plant Dis., 89, 777-1777.

Gisbert, C., Prohens, J. andNuez, F., 2011. Eggplant relatives as sources of variation for developing new rootstocks: Effects of grafting on eggplant yield and fruit apparent quality and composition. Sci. Hort. 128, 14-22.

Gousset, C., Collonnier, C., Mulya, K., Mariska, I., Rotino, G.L., Besse, P., Servaes, A. and Sihachakr, D., 2005. Solanum torvum, as a useful source of resistance againstbacterial and fungal diseases for improvement of eggplant (S. melongena L.).Plant Sci., 168, 319-327.

Grimault, V. and Prior, P., 1994. Grafting tomato cultivars resistant or susceptible tobacterial wilt: analysis of resistance mechanisms. $J$. Phytopathol. 141, 330-334.

Holbrook, N.M., Shashidhar, V.R., James, R.A. andMunns, R., 2002. Stomata control intomato with ABA deficient roots: response of grafted plants to soil drying. $J$. Exp. Bot. 53 (373), 1503-1514.

Hoyos Echeverria, P., 2010. Spanish vegetable production: processing and freshmarket. ChronicaHortic. 49 (4), 27-30.

Hu, C. M., Zhu, Y. L., Yang, L. F., Chen, S. F. and Hyang, Y. M., 2006. Comparison of photosynthetic characteristics ofgrafted and own-root seedling of cucumber under lowtemperature circumstances. Acta Botany Boreal-Occident Sinica, 26: 247-253.

Huang, Y., Tang, R., Cao, Q. andBie, Z., 2009. Improving the fruit yield and quality ofcucumber by grafting onto the salt tolerant rootstock under $\mathrm{NaCl}$ stress. Sci. Hortic. 122, 26-31.

Huitrón-Ramírez, M.V., Ricárdez-Salinas, M. and Camacho-Ferre, F., 2009. Influence ofgrafted watermelon plant density on yield and quality in soil infested with melonnecrotic spot virus. Hort. Sci., 44, $1838-1841$.

Ioannou, N., 2001. Integrating soil solarization with grafting on resistant rootstocksfor 
management of soil-borne pathogens of eggplant. J. Horticult. Sci. Biotechnol., 76, 396-401.

Kays, S.J., 1999. Preharvest factors affecting appearance. Postharvest Biol. Technol.15, 233-247.

Klosterman, S.J., Atallah, Z.K., Vallad, G.E. andSubbarao, K.V., 2009.

Diversity,pathogenicity; and management of Verticillium species. Annual Rev. Phytopathol., 47, 39-62.

Lee, J. M. and Oda, M., 2003. Grafting of herbaceous vegetableand ornamental crops. Horticultural Reviews. 28: 61-124.

Lee, J.M., 2008. Vegetable grafting: a powerful aid for cultivation of environmentallyfriendlyproduce. $\quad K A S T$ Rev. Modern Sci. Technol., 4, 68-85 (The Korean Academyof Science \& Technology).

Lee, J.M., 1994. Cultivation of grafted vegetables. 1 Current status, grafting methods,and benefits. Hortscience, 29, 235-239.

Lenz F., 1970. Effect of fruit on sex expression in eggplant (Solanum melongenaL.). Horticultural Research, 10: 81-82.

Liao, C.T. and Lin, C.H., 1996. Photosynthetic response of grafted bitter melon seedlingto flood stress. Environ. Exp. Bot., 36, 167172.

Liu, H.Y., Zhu, Z.J., Diao, M. andGuo, Z.P., 2006. Characteristic of the sugar metabolism inleaves and fruits of grafted watermelon during fruit development. Plant Physiol. Commun. 42, 8

Liu, N., Zhou, B., Zhao, X., Lu, B., Li, Y. andHao, J., 2009. Grafting eggplant onto tomatorootstock to suppress Verticillium dahliae infection: the effect of root exudates.HortScience 44, 2058-2062.

Louws, F.J., 2010. IPM for soilborne disease management for vegetable and strawberrycrops in SE USA. In: Gisi, U., Chet, I., Gullino, M.L. (Eds.), Plant Pathologyin the 21st Century: Contributions to the 9th International Congress. Recent Developments in Disease Management, Vol. 1, pp. 217-227.

Masuda, M. andGomi, K., 1984. Mineral absorption and oxygen consumption in graftedand non-grafted cucumbers. J. Jpn.
Soc. Hortic. Sci., 54, 414-419.

Matsuzoe, N., Okubo, H. andFujieda, K., 1993. Resistance of tomato plants grafted onSolanum rootstocks to bacterial wilt and root-knot nematode. J. Japn. Soc. Horticult. Sci., 61, 865-872.

Miguel, A., 2004. Use of grafted cucurbits in the Mediterranean region as an alternativeto methyl bromide. In: Proc. Int. Conf. Alternatives to Methyl BromidePortugal, pp. 75-80.

Nakaho, K., Hibino, H. andMiyagawa, H., 2000. Possible mechanisms limitingmovement of Ralstonia solanacearum in resistant tomato tissues. J. Phytopathol.PhytopathologischeZeitschrift, 148, 181190.

Oda, M., 1995. New grafting methods for fruitbearing vegetables in Japan. Jpn. Agricult. Res. Quart., 29, 187-194.

Palada, M.C. and Wu, D.L., 2008. Evaluation of chili rootstocks for grafted sweet pepperproduction during the hot-wet and hot-dry seasons in Taiwan. ActaHortic. 767,167-174.

Paplomatas, E.J., Elena, K. andTsagkarakou, A., 2000. Screening tomato and cucurbitrootstocks for resistance to Verticillium dahliae. Bull. OEPP, 30, 239242.

Paplomatas, E.J., Elena, K., Tsagkarakou, A. andPerdikaris, A., 2002. Control of Verticillium wilt of tomato and cucurbits through grafting of commercial varieties onresistant rootstocks. ActaHorticult. 579, 445-449.

Passam, H.C., Stylianoy, M. andKotsiras, A., 2005. Performance of eggplant grafted ontomato and eggplant rootstocks. Eur. J. Hortic. Sci., 70, 130-134.

Pogonyi, Á., Pék, Z., Helyes, L. andLugasi, A., 2005. Effect of grafting on the tomato'syield, quality and main fruit components in spring forcing. Acta Alimentaria, 34,453-462.

Prior, P., Bart, S., Leclercq, S., Darrasse, A. and Anais, G., 1996. Resistance to bacterial wiltin tomato as discerned by spread of Pseudomonas (Burkholderia) solanacearumin the stem tissues. Plant Pathol., 45, 720-726. 
Proietti, S., Rouphael, Y., Colla, G., Cardarelli, M., De Agazio, M., Zacchini, M.,Moscatello, S. andBattistelli, A., 2008. Fruit quality of mini-watermelon as affectedby grafting and irrigation regimes. J. Sci. Food Agric., 88, 1107-1114.

Pulgar, G., Villora, G., Moreno, D.A. and Romero, L., 2000. Improving the mineral nutritionin grafted watermelon plants: nitrogen metabolism. Biol. Plant. 43, 607609.

Qi, H.Y., Li, T.L., Liu, Y.F. and Li, D., 2006. Effects of grafting on photosynthesis characteristics, yield, and sugar content in melon. J. Shenyang Agric. Univ., 37, 155158.

Qian, Q.Q., Liu, H.Y. and Zhu, Z.J., 2004. Studies on sugar metabolism and related enzymesactivity during watermelon fruit development as influenced by grafting. $J$. Zhejiang Univ., 30, 285-289.

Rivero, R.M., Ruiz, J.M. and Romero, L., $2003 \mathrm{a}$. Can grafting in tomato plants strengthenresistance to thermal stress? $J$. Sci. Food Agric., 83, 1315-1319.

Rivero, R.M., Ruiz, J.M., Sanchez, E. and Romero, L., 2003. Role of grafting in horticulturalplants under stress conditions. Food Agric. Environ., 1, 70-74.

Rodríguez, M.G., Gómez, L., González, F.M., Carrillo, Y., Pi ̃nón, M., Gómez,O., Casanova, A.S., Álvarez, M. andPeteira, B., 2009. Behaviour of genotypesfrom Solanaceae family to manage Meloidogyne incognita (Kofoid y White)Chitwood./Comportamiento de genotipos de la familia Solanaceae frente aMeloidogyne incognita (KofoidyWhite) Chitwood. Revista de Protección Vegetal, 24, 137-145.

Rouphael, Y., Cardarelli, M., Colla, G. and Rea, E., 2008a. Yield, mineral composition, water relations, and water use efficiency of grafted mini-watermelon plantsunder deficit irrigation. HortScience, 43, 730-736.

Ruiz, J.M., Belakbir, A., López-Cantarero, I. and Romero, L., $1997 . \quad$ Leafmacronutrientcontent and yield in grafted melon plants. A model to evaluate the influence ofrootstock genotype. Sci.
Hortic., 71, 227-234. 35-840.

Sakata, Y., Ohara, T. and Sugiyama, M., 2007. The history and present state of the graftingof cucurbitaceous vegetables in Japan. ActaHortic, 731, 159-170.

Sakata, Y., Ohara, T. and Sugiyama, M., 2008. The history of melon and cucumber graftingin Japan. ActaHortic, 767, 217-228.

Salehi-Mohammadi, R., Khasi, A., Lee, S.G., Huh, Y.C., Lee, J.M.andDelshad, M. 2009.Assessing survival and growth performance of Iranian melon to grafting ontoCucurbita rootstocks. Korean J. Hortic. Sci. Technol., 27 (1), 1-6.

Satisha, J., Prakash, G.S., Bhatt, R.M. andSampath Kumar, P., 2007. Physiological mechanisms of water use efficiency in grape rootstocks under drought conditions. Int. J. Agric. Res., 2, 159-164.

Sebahattin, Ç.,Yıldız, D., Sedat, M., Şener, K., Meltem, M., Özgür, A. andGülcan, T., 2009. Grafted eggplant yield, quality and growth in infested soil with Verticillium dahliae and Meloidogyne incognita. Pesq. Agropec. Bras, 44(12), http://dx.doi.org/10.1590/S0100$204 X 2009001200017$.

Shibuya, T., Tokuda, A., Terakura, R., ShimizuMaruo, K., Sugiwaki, H., Kitaya, Y. andKiyota,M., 2007. Short-term bottomheat treatment during low-airtemperaturestorage improves rooting in squash (Cucurbita moschataDuch.) cuttings usedfor rootstock of cucumber (Cucumis sativus L.). J. Jpn. Soc. Hortic. Sci., 76 (2), 139-143.

Siguenza, C., Schochow, M., Turini, T. andPloeg, A., 2005. Use of Cucumis metuliferus as arootstock for melon to manage Meloidogyne incognita. J. Nematol., 37, 276-280.

Suzuki, T. andMorishita, M., 2002. Effects of scion and rootstock cultivars on growth and yield of eggplant cultured under two fertilizer levels. J. Jpn. Soc. Hortic. Sci., 71, 568-574.

Tachibana, S., 1982. Comparison of effects of root temperature on the growth andmineral nutrition of cucumber and figleaf gourd. $J$. Jpn. Soc. Hortic. Sci., 51,299-308. 
Tachibana, S., 1987. Effect of root temperature on the rate of water and nutrientabsorption in cucumber and figleaf gourd. J. Japan. Soc. Hort. Sci., 55, 461-467.

Takahashi, H. and Kawagoe, H., 1971. Escape from cucumber Phytophthora rot by usingrootstock. Agr. Hort., 46, 1581-1584 (In Japanese).

Taussig, C., Izard, D. andErnout, H., 1996. Melon greffé: comment le conduire. PHM, 368, 36-39.

Venema, J.H., Dijk, B.E., Bax, J.M., Van Hasselt, P.R. andElzenga, J.T.M., 2008. Graftingtomato (Solanum lycopersicum) onto the rootstock of a high-altitude accessionof Solanum habrochaites improves suboptimal-temperature tolerance. Environ. Exp. Bot., 63, 359-367.

Venema, J.H., Linger, P., van Heusden, A.W., van Hasselt, P.R. andBrüggemann, W., 2005.The inheritance of chilling tolerance in tomato (Lycopersicon spp.). Plant Biol., 7,118-130.

Wang, S., Yang, R., Cheng, J. and Zhao, J., 2007. Effect of rootstocks on the tolerance tohigh temperature of eggplants under solar greenhouse during summer season.ActaHortic. 761, 357-360.

Wang, W., Vinocur, B. and Altman, A., 2003. Plant responses to drought, salinity andextreme temperatures: towards genetic engineering for stress tolerance. Planta,
$218,1-14$.

Xu, C.Q., Li, T.L. and Qi, H.Y., 2006a. Effects of grafting on development, carbohydratecontent, and sucrose metabolizing enzymes activities of muskmelon fruit. ActaHortic. Sin, 33, 773778.

Xu, C.Q., Li, T.L., Qi, H.Y. and Wang, H., 2006 b. Effects of grafting on developmentand sugar content of muskmelon fruit. $J$. Shenyang Agric. Univ., 37,378-381.

Yao, F.J., Huang, D.F., Zhang, H.M. and Liu, Y.Q., 2003. Effects of rootstocks on growthand fruit quality of grafted watermelon. J. Shanghai Jiaotong Univ., 21, 289-294.

Yetisir, H. and Sari, N., 2003. Effect of different rootstock on plant growth, yield andquality of watermelon. Aust. J. Exp. Agric., 43, 1269-1274.

Yu, X., Xing, Y., Ma, H., Wei, M. and Li, B., 1999. Changes of hormone in grafted and nongraftedcucumber seedlings under low temperature stress. ActaHortic. Sin, 26(6), 406-407.

Zhou, Y.H., Huang, L.F., Zhang, Y., Shi, K., Yu, J.Q. andNogues, S., 2007. Chillinduceddecrease in capacity of RuBP carboxylation and associated $\mathrm{H}_{2} \mathrm{O}_{2}$ accumulationin cucumber leaves are alleviated by grafting onto Figleaf Gourd. Ann. Bot., 100,839-848.

\section{How to cite this article:}

Shriram Ratan Pradhan, G.S. Sahu, P. Tripathy, S.K. Dash, B. Mishra, R. Jena and Sahoo, T.R. 2017. Vegetable Grafting: A Multidimentional Approach for Crop Management in Vegetables. Int.J.Curr.Microbiol.App.Sci. 6(10): 3332-3345. doi: https://doi.org/10.20546/ijcmas.2017.610.390 